\title{
Effect of prior bronchoconstriction on the airway response to histamine in normal subjects
}

\author{
KF CHUNG, PD SNASHALL
}

From the Department of Medicine, Charing Cross Hospital Medical School, London

ABSTRACT We have examined the effect of prior bronchoconstriction on the bronchial responsiveness to inhaled histamine in nine normal subjects. The airway response to increasing concentrations of histamine aerosol was assessed by measurement of specific airways conductance (sGaw) in a body plethysmograph. The threshold provocative dose of histamine needed to cause a 35\% fall in starting sGaw $\left(\mathrm{PD}_{35}\right)$ and the steepest slope of the response were measured from cumulative log dose response curves. Histamine challenges were performed in duplicate after premedication with $0.9 \%$ sodium chloride (control) or methacholine aerosol on separate days. The mean starting sGaw did not change significantly after inhalation of $0.9 \%$ sodium chloride but methacholine caused a mean reduction in sGaw of $42 \%$. Mean control $\mathrm{PD}_{35}$ values did not differ significantly from mean $\mathrm{PD}_{35}$ values after methacholine. The mean steepest slope of the response after methacholine was $47 \%$ lower than the mean control value. There was a significant linear relationship between starting sGaw and the steepest slope for the control and for the methacholine premedicated challenges. The reduction in slope after methacholine was accounted for by the fall in starting sGaw. Because histamine $\mathrm{PD}_{35}$ was not altered by prior bronchoconstriction, it is concluded that the bronchial hyperresponsiveness of asthmatic subjects to non-specific bronchoconstrictor stimuli is unlikely to be a direct consequence of their low starting airway calibre.

It has been proposed that one factor causing increased responsiveness of the airways of asthmatic subjects to bronchoconstrictor stimuli is their low starting airway calibre. ${ }^{1}$ In a previous study, ${ }^{2}$ in which the airway response to histamine aerosol was characterised as the dose required to lower specific airway conductance (sGaw) by $35 \%$ (that is, $\mathrm{PD}_{35}$ ), we found that asthmatic subjects had a lower $\mathrm{PD}_{35}$ than normal subjects. On average, the asthmatic patients had lower airway conductance before bronchial challenge than normal subjects. When they were given bronchodilator (atropine or salbutamol) to bring prechallenge sGaw to within the normal range, $\mathrm{PD}_{35}$ also increased to within the normal range.

We wondered whether this increase in $\mathrm{PD}_{35}$ could have been a direct effect of bronchodilatation in the manner previously proposed. ${ }^{1}$ The aim of the pres-

Address for reprint requests: Dr PD Snashall, Department of Medicine, Charing Cross Hospital Medical School, London W6 8RF.

Accepted 23 September 1983 ent study was to examine the effect of a prior reduction in airway calibre on the bronchial response to histamine. We have investigated whether pretreatment of normal subjects with a long acting bronchoconstrictor agent, methacholine, would result in bronchial hyperresponsiveness.

\section{Methods}

Nine normal, non-asthmatic subjects (table 1) were studied. They all gave informed consent to the study, which was approved by the Charing Cross Hospital ethical committee. None of the subjects suffered from hayfever or had a respiratory infection at the time of the study or during the preceding month. Subjects were asked not to smoke and not to drink caffeine containing beverages within two hours of the start of each study.

Airway calibre was assessed by determination of airways resistance in a constant volume body plethysmograph (Fenyves and Gut, Basel, Switzerland). For each measurement, the subject panted at a frequency of 1-2 cycles per second, ${ }^{3}$ and thoracic 
Table 1 Characteristics and baseline values of FEV (means with $S D$ in parentheses) and specific airway conductance (sGaw) of nine normal subjects.

\begin{tabular}{|c|c|c|c|c|c|c|c|}
\hline \multirow{2}{*}{$\begin{array}{l}\text { Sex } \\
(M: F)\end{array}$} & \multirow{2}{*}{$\begin{array}{l}\text { Age } \\
(y)\end{array}$} & \multirow[t]{2}{*}{ Atopic* } & \multirow[t]{2}{*}{ Smoker } & \multirow{2}{*}{$\begin{array}{l}\text { Height } \\
(m)\end{array}$} & \multicolumn{2}{|c|}{$F E V_{1}(l B T P S)$} & \multirow{2}{*}{$\underset{\left(s^{-1} k P a^{-1}\right)}{s a w}$} \\
\hline & & & & & Observed & Predicted $\dagger$ & \\
\hline $5: 4$ & $\begin{array}{l}25.0 \\
(2 \cdot 6)\end{array}$ & 2 & 1 & $\begin{array}{l}1.73 \\
(0.07)\end{array}$ & $\begin{array}{c}3.81 \\
(0.44)\end{array}$ & $\begin{array}{l}3 \cdot 83 \\
(0.57)\end{array}$ & $\begin{array}{l}1.94 \\
(0 \cdot 40)\end{array}$ \\
\hline
\end{tabular}

*Positive skin prick test responses to more than four common allergens.

†From Cotes JE. Lung function: assessment and application in medicine. Oxford: Blackwell, 1975:390.

gas volume (TGV) was measured simultaneously. Specific airways conductance $(\mathrm{sGaw}=($ Raw $\times$ TGV) $)^{-1}$ in $\mathrm{s}^{-1} \mathrm{kPa}^{-1}$ ) was calculated.

Histamine acid phosphate (molecular weight $=$ 308 ) dissolved in water was delivered intermittently as an aerosol from a Hudson nebuliser attached to a breath activated "dosimeter," 4 delivering $8 \mu \mathrm{l}$ of aerosol per puff. The nebuliser was triggered by a fall of mouth pressure at the onset of inspiration for $0 \cdot 6 \mathrm{~s}$. The same nebuliser was used throughout the experiment.

After five measurements of resting sGaw over a period of 30 seconds, the subject took five slow, deep breaths of histamine aerosol, beginning from functional residual capacity. Inhalation of histamine aerosol was repeated at three minute intervals, the concentration of histamine being doubled with each repetition. The concentrations ranged from 1.63 to $208 \mathrm{mmol} \mathrm{l}^{-1}(0 \cdot 5-64 \mathrm{mg} / \mathrm{ml})$ and the number of doses inhaled ranged from 6 to 9 . Five sGaw measurements were made every two minutes after the inhalation of each concentration of histamine. Each challenge was terminated when sGaw had fallen by $50-70 \%$, at which point the subject was aware of moderate chest tightness and wheeziness. This was promptly relieved by the inhalation of $200 \mu \mathrm{g}$ salbutamol from an inhaler. Subjects avoided coughing and taking deep breaths, particularly during the phase of bronchoconstriction. The histamine challenge study took 20-25 minutes.

Each subject performed four histamine challenges on separate days. The first challenge was premedicated with $40 \mu$ l of $0.9 \%$ sodium chloride solution (control); the remaining three challenges were in random order. Two of these challenges were performed after premedication with inhaled methacholine hydrochloride $128 \mathrm{mmol} \mathrm{l}^{-1}(25 \mathrm{mg} /$ $\mathrm{ml})$ to reduce starting sGaw by about $50 \%$. Seven subjects received $40 \mu \mathrm{l}(5 \cdot 1 \mu \mathrm{mol})$ of methacholine and two subjects $80 \mu \mathrm{l}(10 \cdot 2 \mu \mathrm{mol})$. A further control challenge with saline as premedication was performed to assess reproducibility. In each case the premedicating aerosol was inhaled five minutes before the first dose of histamine. Measurements of sGaw were made two and four minutes before the start of histamine challenge. The subjects were unaware of the nature of the premedicating solutions. At least 48 hours elapsed between successive challenge studies.

The arithmetic mean of each set of five measurements was plotted against the logarithm to base 10 of the cumulative dose of histamine delivered to the subject. Each dose response curve had an initial horizontal portion followed by a fall. As previously described, ${ }^{2}$ we determined from each curve $(a)$ starting sGaw, measured after inhalation of premedicating drug; $(b)$ the cumulative dose of histamine that produced a $35 \%$ fall in sGaw $\left(\mathrm{PD}_{35}\right)$; and $(c)$ the steepest slope of the response.

It was important to determine that methacholine was producing bronchoconstriction which was sustained for the 20-25 minutes required to define the dose response relationship to histamine. We therefore studied the duration of effect of methacholine on seven normal subjects, three of whom were subjects for the main experiment. Four of these subjects inhaled $40 \mu \mathrm{l}$ and the remaining three subjects $80 \mu \mathrm{l}$ of $2.5 \%$ methacholine hydrochloride solution to obtain a $40-50 \%$ fall in resting sGaw. Five measurements of sGaw were made at specific times after inhalation of methacholine-namely, at 2, 4, 6, and 10 minutes and subsequently at five minute intervals until the 40th minute.

The responses of the two control histamine challenges were compared with a paired $t$ test and those of all four challenges were compared with a two factor analysis of variance. ${ }^{5}$ We accepted a $p$ value of $<0.05$ as indicating a significant difference. All results are quoted as means with standard deviations in parentheses.

\section{Results}

METHACHOLINE INDUCED

BRONCHOCONSTRICTION (fig 1)

Methacholine reduced mean sGaw from $1.75(0.54)$ $\mathrm{s}^{-1} \mathrm{kPa}^{-1}$ to $0.90(0.29) \mathrm{s}^{-1} \mathrm{kPa}^{-1}$ by 2 minutes after inhalation (fig 1). Mean sGaws at 4, 6, 10, 15, 20, and 25 minutes did not differ significantly from mean sGaw at 4 minutes (paired $t$ test), indicating 


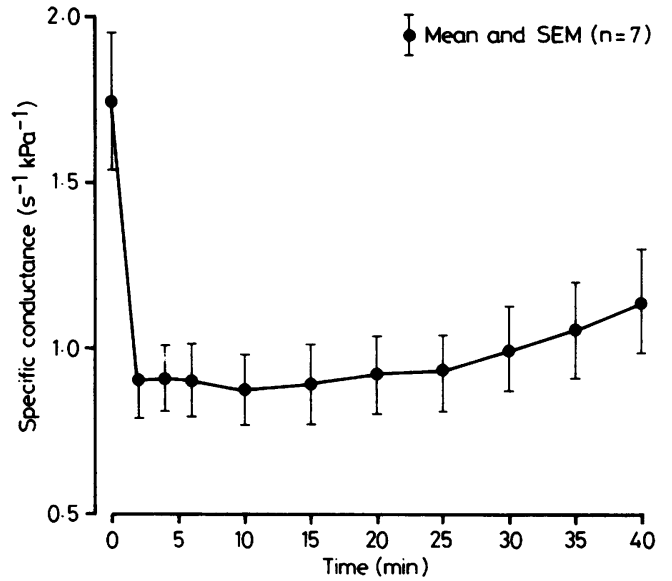

Fig 1 Time course of the effect of methacholine on mean specific airway conductance in seven normal subjects (bars indicate SEM). Maximum bronchoconstriction was achieved within two minutes and was sustained for 25 minutes.

that bronchoconstriction was sustained for 25 minutes. By 30,35 , and 40 minutes mean sGaw had increased significantly $(p<0.05)$.

\section{CONTROL AND METHACHOLINE PREMEDICATED} HISTAMINE CHALLENGES (figs 2 and 3)

The mean initial sGaw for the first set of control challenges was $1.85(0.28) \mathrm{s}^{-1} \mathrm{kPa}^{-1}$ and was not significantly changed after inhalation of $0.9 \%$

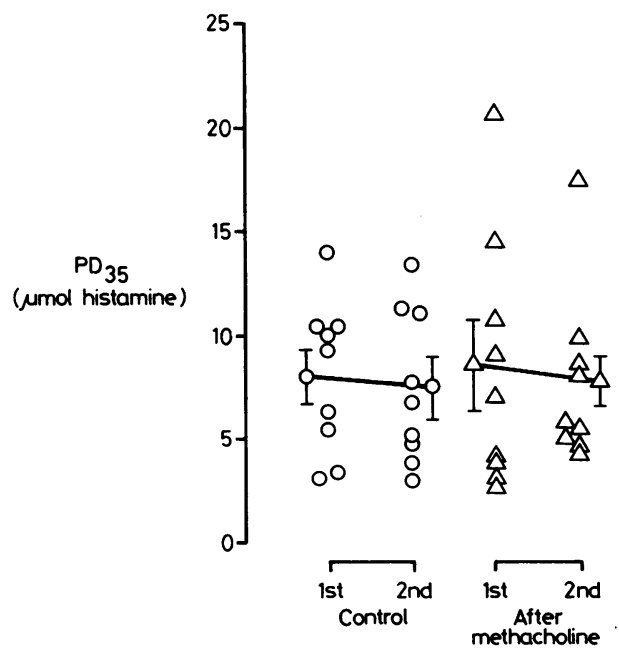

Fig 2 Individual $P D_{35}$ values for histamine, with means and SEM, after premedication with $0.9 \%$ sodium chloride (O) and methacholine $(\triangle)$, which caused a mean fall of $40 \%$ from the starting specific conductance.

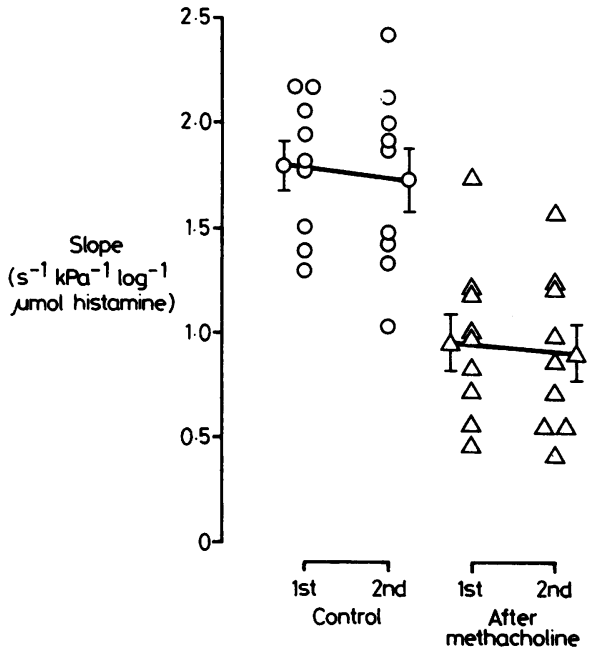

Fig 3 Individual values of slopes of histamine dose response curves, with means and SEM, after premedication with $0.9 \%$ sodium chloride $(O)$ and methacholine $(\triangle)$. After bronchoconstriction with methacholine there was a mean fall in slope of about $45 \%$ in both sets of challenges.

sodium chloride solution at $1.98(0.28) \mathrm{s}^{-1} \mathrm{kPa}^{-1}$. The geometric mean $\mathrm{PD}_{35}$ was $7 \cdot 19 \mu$ mol histamine and the mean steepest slope was $1.80(0.33)$ $\mathrm{s}^{-1} \mathrm{kPa}^{-1} \log ^{-1} \mu \mathrm{mol}$ histamine (table 2). The mean starting sGaw, mean $\mathrm{PD}_{35}$, and mean steepest slope for the second set of control challenges were not significantly different from those of the first challenge $(p>0.25)$. The within subject coefficients of variation for $\mathrm{PD}_{35}$ and steepest slope were $27 \%$ and $24 \%$ respectively.

For the first methacholine premedicated challenge the mean initial sGaw fell from $1.96(0.43)$ to 1.13 $(0.30) \mathrm{s}^{-1} \mathrm{kPa}^{-1}$ after methacholine $(\mathrm{p}<0.005)$. The geometric mean $\mathrm{PD}_{35}$ was $6.71 \mu \mathrm{mol}$ histamine $(-3.5+7.4 \mathrm{SD})$ and the mean steepest slope was $0.96(0.39) \mathrm{s}^{-1} \mathrm{kPa}^{-1} \log ^{-1} \mu \mathrm{mol}$ histamine.

A similar degree of bronchoconstriction was obtained for the second methacholine premedicated challenge, with mean sGaw falling from $1.93(0.40)$ to $1.13(0.25) \mathrm{s}^{-1} \mathrm{kPa}^{-1}$ after methacholine. Geometric mean PD $_{35}$ was $7.08(-2.5+3.9$ SD) $\mu \mathrm{mol}$ histamine and mean steepest slope was 0.91 $(0.39) \mathrm{s}^{-1} \mathrm{kPa}^{-1} \log ^{-1} \mu \mathrm{mol}$ histamine. There was no significant difference between the $P_{35}$ values obtained for all four sets of challenges $(F$ ratio $=$ $0 \cdot 15, p>0 \cdot 25)$ but there was a significant difference between the four sets of slopes ( $F$ ratio $=19 \cdot 7, p<$ 0.0001). Thus prior bronchoconstriction with methacholine did not alter $\mathrm{PD}_{35}$ but resulted in a significant fall in slope.

The dose response curves obtained from four sub- 
Table 2 Individual starting values of $s G a w, P D_{3 y}$ and steepest slopes for histamine challenges

\begin{tabular}{|c|c|c|c|c|c|c|c|c|c|c|c|c|c|c|}
\hline \multirow{2}{*}{$\begin{array}{l}\text { Subject } \\
\text { No }\end{array}$} & \multicolumn{3}{|c|}{ Ist control } & \multicolumn{3}{|c|}{ 2nd control } & \multicolumn{4}{|c|}{ Ist postmethacholine* } & \multicolumn{4}{|c|}{ 2nd postmethacholine $\ddagger$} \\
\hline & $\begin{array}{l}\text { Starting } \\
s G a w^{*}\end{array}$ & $P D_{35}$ & $\begin{array}{l}\text { Steepest } \\
\text { slope }\end{array}$ & $\begin{array}{l}\text { Starting } \\
\text { sGaw }^{*}\end{array}$ & $P D_{35}$ & $\begin{array}{l}\text { Steepest } \\
\text { slope }\end{array}$ & $\begin{array}{l}\text { Baseline } \\
\text { sGaw } \dagger\end{array}$ & $\begin{array}{l}\text { Starting } \\
\text { sGaw* }\end{array}$ & $P D_{35}$ & $\begin{array}{l}\text { Steepest } \\
\text { slope }\end{array}$ & $\begin{array}{c}\text { Baseline } \\
\text { sGaw } \dagger\end{array}$ & $\begin{array}{l}\text { Starting } \\
\text { sGaw }^{*}\end{array}$ & $P D_{35}$ & $\begin{array}{l}\text { Steepest } \\
\text { slope }\end{array}$ \\
\hline $\begin{array}{l}1 \\
2 \\
3 \\
4 \\
5 \\
6 \\
7 \\
8 \\
9 \\
\text { Mean } \\
\text { SD }\end{array}$ & $\begin{array}{l}1.60 \\
1.98 \\
1.37 \\
2.10 \\
2.10 \\
2.10 \\
1.96 \\
1.62 \\
1.83 \\
1.85 \\
0.27\end{array}$ & $\begin{array}{c}10 \cdot 4 \\
10 \cdot 1 \\
6 \cdot 4 \\
9 \cdot 4 \\
5 \cdot 5 \\
3 \cdot 1 \\
10 \cdot 4 \\
3 \cdot 3 \\
14 \cdot 0 \\
7 \cdot 19 \S \\
-2 \cdot 9,+5 \cdot 1\end{array}$ & $\begin{array}{l}1.30 \\
2.06 \\
1.40 \\
1.79 \\
1.95 \\
2.18 \\
2.18 \\
1.51 \\
1.81 \\
1.80 \\
0.33\end{array}$ & $\begin{array}{l}1.64 \\
2.13 \\
1.56 \\
1.96 \\
2.46 \\
2.10 \\
1.80 \\
2.05 \\
2.13 \\
1.98 \\
0.28\end{array}$ & $\begin{array}{c}7 \cdot 8 \\
11 \cdot 4 \\
3 \cdot 9 \\
6 \cdot 8 \\
5 \cdot 2 \\
4 \cdot 9 \\
13 \cdot 5 \\
2 \cdot 9 \\
11 \cdot 4 \\
6 \cdot 68 \S \\
-2 \cdot 8,+4 \cdot 5\end{array}$ & $\begin{array}{l}1.43 \\
1.92 \\
1.03 \\
2.13 \\
2.44 \\
1.87 \\
1.33 \\
1.99 \\
1.48 \\
1.74 \\
0.45\end{array}$ & $\begin{array}{l}1.58 \\
2.88 \\
1.38 \\
2.07 \\
1.74 \\
2.13 \\
1.98 \\
1.74 \\
2.12 \\
1.96 \\
0.43\end{array}$ & $\begin{array}{l}1.15 \\
1.64 \\
0.62 \\
1.20 \\
1.06 \\
1.02 \\
0.95 \\
0.99 \\
1.50 \\
1.13 \\
0.30\end{array}$ & $\begin{array}{c}7 \cdot 0 \\
10 \cdot 9 \\
4 \cdot 2 \\
20 \cdot 8 \\
3 \cdot 1 \\
2 \cdot 6 \\
9 \cdot 1 \\
3 \cdot 9 \\
14 \cdot 6 \\
6 \cdot 718 \\
-3 \cdot 5,+7 \cdot 4\end{array}$ & $\begin{array}{l}1.18 \\
1.75 \\
0.46 \\
0.96 \\
1.20 \\
0.56 \\
0.72 \\
1.00 \\
0.84 \\
0.96 \\
0.39\end{array}$ & $\begin{array}{l}1.37 \\
2.63 \\
1.37 \\
2.12 \\
1.83 \\
2.07 \\
2.09 \\
1.80 \\
2.09 \\
1.93 \\
0.40\end{array}$ & $\begin{array}{l}0.95 \\
1.38 \\
0.78 \\
1.39 \\
1.14 \\
0.77 \\
1.42 \\
1.20 \\
1.11 \\
1.13 \\
0.25\end{array}$ & $\begin{array}{c}9 \cdot 9 \\
4 \cdot 9 \\
5 \cdot 6 \\
8 \cdot 1 \\
5 \cdot 7 \\
5 \cdot 2 \\
8 \cdot 6 \\
4 \cdot 6 \\
17 \cdot 6 \\
7 \cdot 08 \S \\
-2 \cdot 5,+3 \cdot 9\end{array}$ & $\begin{array}{l}0.55 \\
0.99 \\
0.54 \\
0.87 \\
1.24 \\
0.42 \\
1.59 \\
1.22 \\
0.72 \\
0.91 \\
0.39\end{array}$ \\
\hline
\end{tabular}

*Measured four minutes after inhalation of $0.9 \%$ sodium chloride (control) or methacholine.

†Measured before methacholine.

$\ddagger$ All subjects inhaled $40 \mu \mathrm{l}$ of methacholine $2.5 \%$ except for subjects 7 and 9 , who inhaled $80 \mu \mathrm{l}$.

$\S$ Geometric mean.

jects are shown in figure 4 and the values for starting sGaw, $\mathrm{PD}_{35}$, and steepest slope for each subject are shown in table 2 .

\section{RELATIONSHIP BETWEEN STARTING SGaw AND SLOPE AND BETWEEN STARTING SGaw AND PD (figs 5 and 6)}

There was a significant linear relationship between starting sGaw and slope for the 18 control and for the 18 methacholine premedicated challenges (fig 5 ). There was no significant difference in the slopes of these two regression lines $(p>0 \cdot 1)$, but their positions were significantly different $(p<0.001)$. There was no significant linear relationship between starting sGaw and $\mathrm{PD}_{35}$ (fig 6).

\section{Discussion}

In these studies we have reduced airway conductance before histamine challenge into the range previously observed in asthmatic subjects. ${ }^{2}$ This manoeuvre did not increase bronchial responsiveness to histamine; $\mathrm{PD}_{35}$ for normal subjects remained five times higher than that of asthmatics. These findings do not support the hypothesis that the hyperreactivity of the asthmatic is a consequence of his reduced starting airway calibre.

The effect of bronchoconstriction on the slope of the response was predictable from our previous findings. ${ }^{26}$ We have found with both histamine and methacholine challenges a positive linear correlation between starting airway conductance and slope for

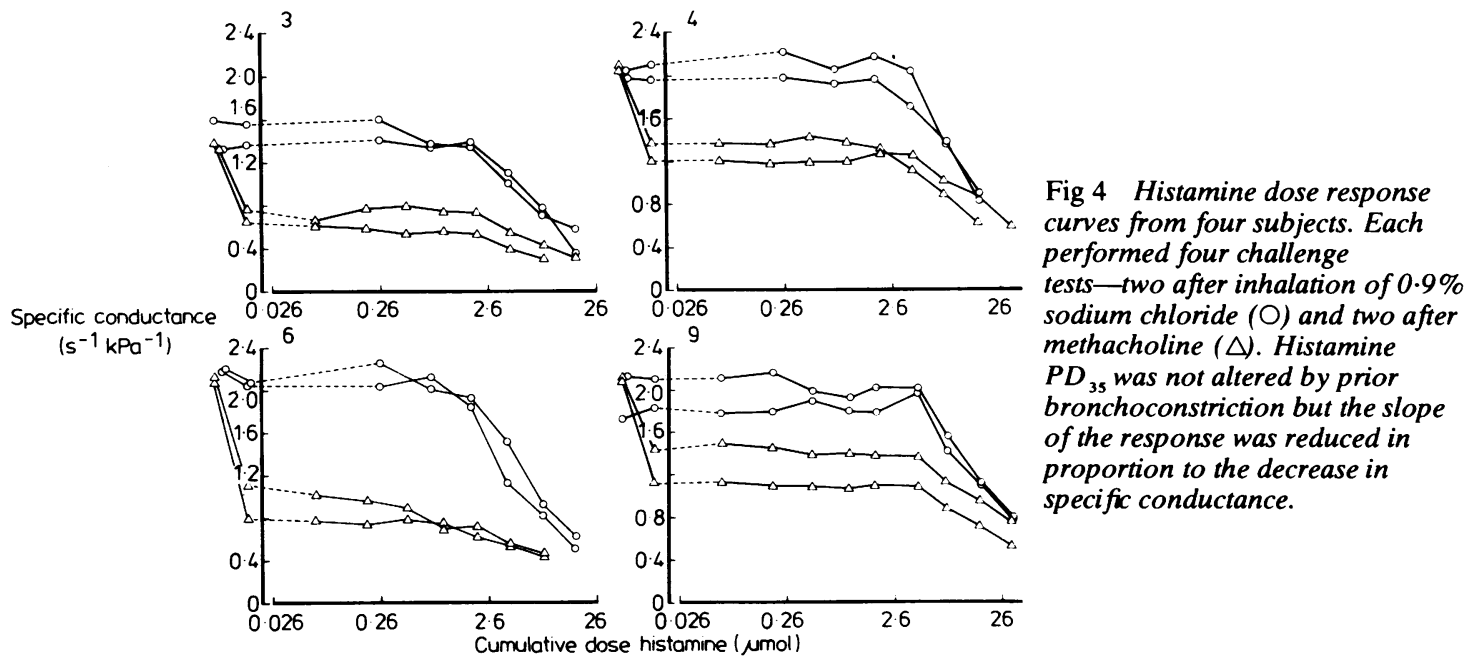

Fig 4 Histamine dose response curves from four subjects. Each performed four challenge methacholine $(\triangle)$. Histamine $P D_{35}$ was not altered by prior bronchoconstriction but the slope of the response was reduced in proportion to the decrease in specific conductance. 


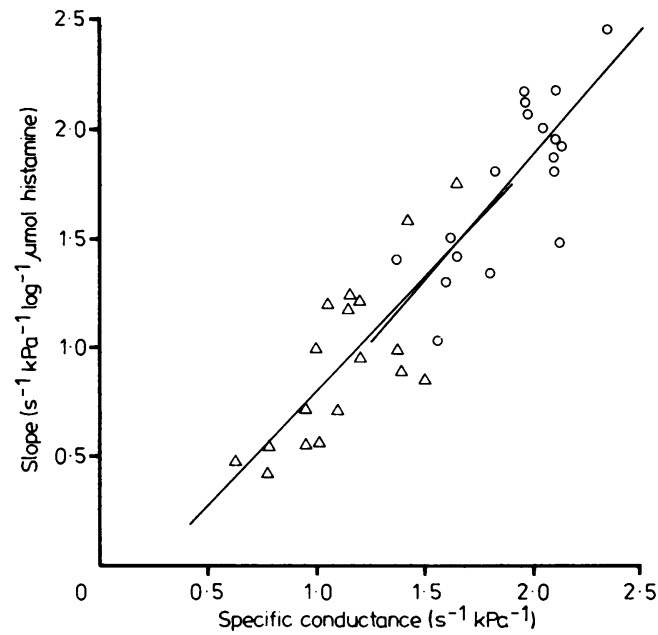

Fig 5 Relationship between starting specific conductance and steepest slope for challenges after $0.9 \%$ sodium chloride $(\mathrm{O}, n=18)$ and methacholine $(\triangle, n=18)$. The linear regression lines for placebo challenges $(y=1 \cdot 14 x-0 \cdot 40$, $r=0.78, p<0.001)$ and for methacholine premedicated challenges $(y=1.04 x-0.24, r=0.74, p<0.001)$ are shown.

both spontaneous changes and drug induced increases in airway calibre. Thus bronchodilatation results in an increase in the steepest slope, and we have now shown a reduction in slope after bronchoconstriction. The relationship between starting conductance and slope was quantitatively similar to

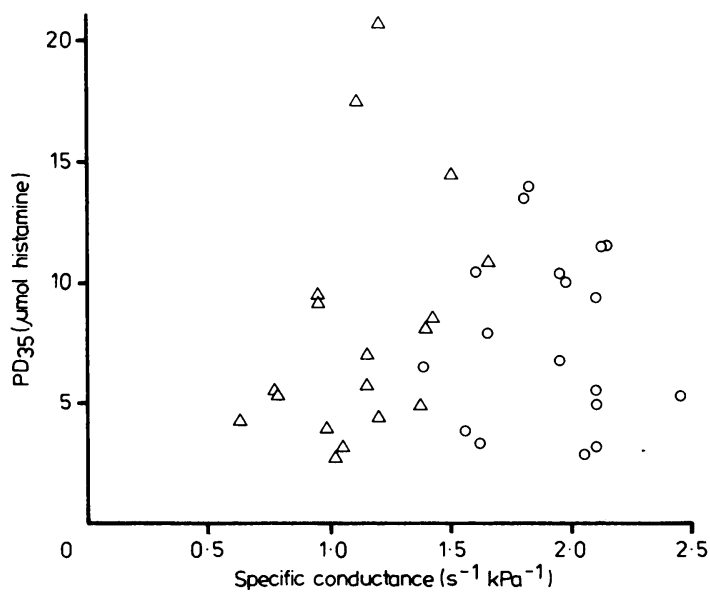

Fig 6 Relationship between starting specific conductance and $P D_{35}$ for challenges after $0.9 \%$ sodium chloride (O, $r=0.02, p>0.25$ ) and after methacholine $(\triangle r=0.37, p>0.05)$. our previous findings, a halving the prechallenge airway conductance resulting in an approximate halving of the slope. This is an important relationship because it implies that when dose response curves from control challenges and after bronchoconstriction are adjusted by expressing airway conductance as percentage changes of the starting value they will be roughly parallel or superimposed (fig 7), and if this is so then a single value for the intercept $\mathrm{PD}_{35}$ describes their position. Since the regression lines shown in figure 5 do not pass through the origin, "normalisation" will result in a small error.

Our observation that prior bronchoconstriction did not alter bronchial responsiveness to histamine is interesting in the light of factors which have been suggested to increase the normalised slope and decrease the intercept of the dose response curve. The hyperbolic relationship between airways resistance and calibre (Poiseuille's law), the presence of a thicker bronchial wall, ${ }^{7}$ and the increase in activity of airway irritant receptors with bronchoconstriction $^{8}$ may result in an amplification of the bronchoconstrictor response and therefore in a steeper slope. In the bronchoconstricted state airway smooth muscle may be operating on a steeper part of its length tension curve, such that less histamine may be needed to induce a response and a greater degree of airway narrowing would result.' Differences in aerosol deposition may also be expected to alter the $\mathrm{PD}_{35}$. A more central deposi-

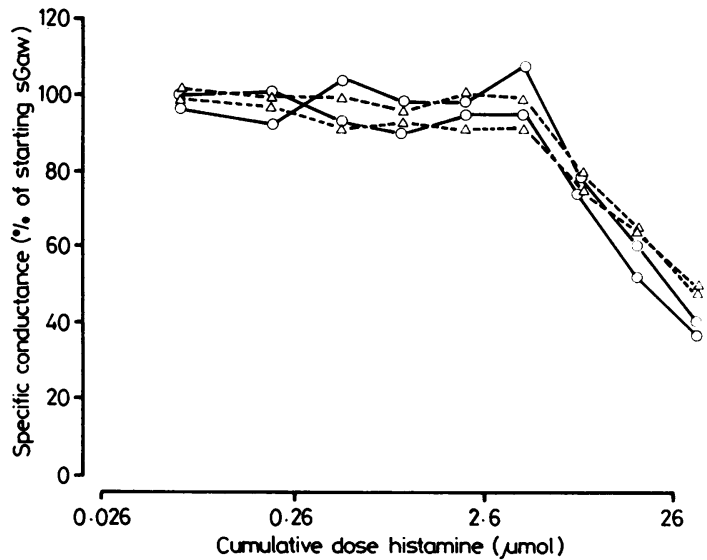

Fig 7 Histamine dose response curves for one subject with specific conductance expressed as percentages of starting $s$ Gaw. Challenges were obtained after premedication with $0.9 \%$ sodium chloride $(\mathrm{O}-\mathrm{O})$ and after methacholine $(\triangle-\cdots-\triangle)$. These curves (obtained from subject 9 - see fig 4) have been superimposed after "normalisation" for the starting value of sGaw. 
tion of inhaled aerosol is seen in the bronchoconstricted state $^{9}$ and Ruffin and colleagues ${ }^{10}$ have shown that asthmatic subjects needed much less histamine to cause a response when aerosol was deposited in the central airways than when the histamine is deposited in central and peripheral airways.

The relationship between airway calibre and responsiveness is more complex in the asthmatics and it may be difficult to dissociate changes in airway calibre from accompanying changes in airway responsiveness if both events result from similar factors. Thus during an attack of clinical asthma both the airway narrowing and airway hyperresponsiveness may be caused by bronchial inflammation and oedema. In our previous studies of asthmatic patients, in a stable clinical condition, ${ }^{26}$ we found no relationship between prechallenge airway conductance and the $\mathrm{PD}_{35}$ for histamine or methacholine, but in a group of patients with more severe asthma we may expect to find that the most severely affected have the lowest airway calibre and the highest responsiveness. ${ }^{11-13}$ The present study on normal subjects, however, suggests that these two factors can be separated, as does the demonstration of an increased responsiveness in normal subjects after upper respiratory tract viral infections ${ }^{14}$ or brief exposure to pollutants ${ }^{1516}$ without any accompanying changes in airway calibre. Our results suggest that the airway hyperresponsiveness of the asthmatic is not the consequence of a reduction in starting airway calibre per se.

\section{References}

${ }^{1}$ Benson MK. Bronchial hyperreactivity. Br J Dis Chest 1975;69:227-37.

${ }^{2}$ Chung KF, Morgan BM, Keyes SJ, Snashall PD. Histamine dose-response relationships: importance of starting airway calibre. Am Rev Respir Dis 1982;126:849-54.
${ }^{3}$ Dubois AB, Bothelho SY, Comroe JH. A new method for measuring airway resistance in man using a body plethysmograph: values in normal subjects and patients with respiratory disease. J Clin Invest 1956;35:327-35.

${ }^{4}$ Rosenthal RR, Norman PS, Summer WR, Permutt S. Role of the parasympathetic system in antigeninduced bronchoconstriction. J Appl Physiol 1977; 42:600-6.

${ }^{5}$ Winer BJ. Statistical principles in experimental design. 2nd ed. New York: McGraw-Hill, 1971:309-32.

${ }^{6}$ Chung KF, Morgan BM, Snashall PD. Effects of pharmacologic antagonist activity and bronchodilatation on the bronchial dose response curve to methacholine. Clin Sci 1983;64:49P (abstract).

${ }^{7}$ Freedman BJ. The functional geometry of the bronchi: The relationship between changes in external diameter and calibre, and a consideration of the passive role played by the mucosa in bronchoconstriction. Bull Physiopath Respir 1972;8:545-51.

${ }^{8}$ Mills JE, Sellick M, Widdicombe JG. Activity of lung irritant receptors in pulmonary microembolism, anaphylaxis and drug-induced bronchoconstriction. $J$ Physiol (Lond) 1969;203:337-57.

9 Dolovich M, Ryan G, Newhouse MT. Aerosol penetration into the lung. Chest $1981 ; 80$, suppl:834-6.

${ }^{10}$ Ruffin RE, Dolovich MB, Wolff RK, Newhouse MT. The effects of preferential deposition of histamine in the human airway. $A m$ Rev Respir Dis 1978;117:485-92.

${ }^{11}$ Parker CD, Bilbo RE, Reed CE. Methacholine aerosol as a test for bronchial asthma. Arch Intern Med 1965;115:453-8.

12 Makino S. Clinical significance of bronchial sensitivity to acetylcholine and histamine in bronchial asthma. $J$ Allergy 1966;38:127-42.

${ }^{13}$ Itkin JH. Bronchial hypersensitivity to mecholyl and histamine in asthmatic subjects. $J$ Allergy 1967;40:24456.

${ }^{14}$ Empey DW, Laitinen WA, Jacobs L, Gold WM, Nadel JA. Mechanisms of bronchial hyperreactivity in normal subjects after respiratory tract infection. Am Rev Respir Dis 1976;113:131-6.

15 Golden JA, Nadel JA, Boushey HA. Bronchial hyperreactivity in healthy subjects after exposure to ozone. Am Rev Respir Dis 1978;118:287-94.

${ }^{16}$ Walters EH, Parrish RW, Bevan C, Smith AP. Induction of bronchial hypersensitivity: evidence for a role for prostaglandins. Thorax 1981;36:571-4. 